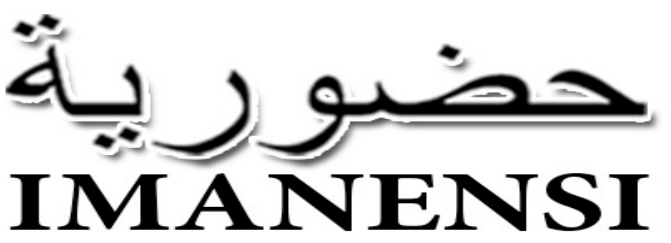

(Jurnal Ekonomi, Manajemen, dan Akuntansi Islam)

Vol 4, No 1, Maret 2019, Hlmn. 1-13

\title{
Islam dan riset akuntansi
}

Sirajudin

Politeknik Negeri Banjarmasin, Jl. Brig Jend. Hasan Basri BanjarmasinKalimantan selatan, Indonesia 70124

1*sirajudin@poliban.ac.id

doi: 10.34202/imanensi.4.1.2019.1-13.

\begin{abstract}
Abstrak
Tulisan ini berupaya mengurai sekilas paradigma apa saja yang menjadi perhatian di riset akuntansi termasuk filosofi yang mendasarinya. Tulisan ini juga mencoba menawarkan gambaran riset akuntansi yang ada dan paradigma Islam sebagai sebuah paradigma tersendiri yang bisa digunakan dalam riset-riset akuntansi yang bagi sebagian peneliti termasuk dalam paradigma spiritualitas. Metode yang digunakan adalah telaah literatur atas beberapa tulisan tentang paradigm Islam dan riset akuntansi. Temuannya bahwa paradigm Islam sudah sejak lama menjadi kacamata tersendiri dalam riset-riset sosial, termasuk riset di bidang akuntansi. Namun, mayoritas peneliti cenderung mengklasifikasikan paradigma Islam ke ranah paradigma posmoderen atau paradigma spritualis.
\end{abstract}

Kata Kunci: Paradigma; Pengetahuan; Spiritualitas dan Paradigma Islam.

\section{Abstract}

This article tries to extract a glace about any paradigm that concerned and also the philosophical basis. It offers the picture of accounting research and Islamic paradigm as a self paradigm that can implement in accounting researsches. It may consider as spiritual paradigm to some researcher. The method it this article is literature review on some writings about Islamic paradigm and accounting research. The finding shows that Islamic paradigm has well known as a specific tool in social research, as it is in accounting research. However, most researchers tend to classify it as postmodern or spiritual paradigm.

Keywords: Paradigm; Knowledge; Spirituality and Islamic Paradigm.

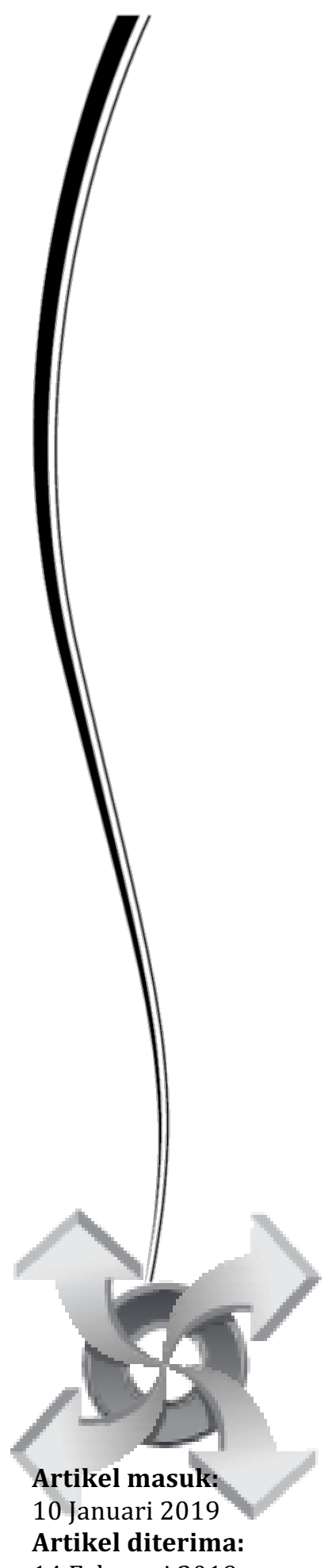

14 Februari 2019 
Perkembangan praktik akuntansi dewasa ini seakan terus melesat laju merujuk perkembangan dan keadaan yang ada di beberapa negara maju (Barat). Hal ini bisa dilihat dari diberlakukannya penyesuaian standar akuntansi di Indonesia sejak 2010 dan pengadopsian IFRS seutuhnya di 2012 bagi perusahaan publik ${ }^{1}$ di Indonesia (Cahyonowati \& Ratmono, 2012; Suprihatin \& Tresnaningsih, 2013). IFRS merupakan standar pelaporan keuangan international yang bertujuan agar laporan keuangan yang ada secara global termasuk di Indonesia agar bisa dengan mudah dibaca oleh semua pihak (termasuk calon investor dari luar negeri/asing). Standar ini seakan menjadi menara gading bagi semua perusahaan yang ada di Indonesia. Sebuah standar yang mengakomodir kegiatan yang ada di pasar keuangan yang sarat dengan kepentingan pemodal alias investor (Putralie, Syahputra, \& Zul, 2011).

Pengadopsian IFRS di Indonesia bisa disebut sebagai sebuah langkah harmonisasi atas keragaman akuntansi Indonesia. Hal ini bisa dilihat dari adanya pengakomodiran standar akuntansi syariah dan standar entitas tanpa akuntabilitas publik (ETAP) selain pemberlakukan IFRS sebagai pengganti standar akuntansi keuangan (Saito, Hiramatsu, \& Mayangsari, 2012; Terizaghi \& Fitriasuri, 2014). Pengakomodiran akuntansi syariah tidak lepas dari peran para peneliti dan praktisi keuangan syariah dunia yang sejak tahun 80an dan 90an seiring dengan bermunculannya lembaga keuangan Islam. Sebelum bermunculannya lembaga keuangan Islam tersebut, sudah ramai diskusi tentang gerakan Islamisasi ilmu pengetahuan yang diawali oleh tulisan Sayyed Husein Nashr tahun 60an yang diikuti oleh Al Faruqi dan Al Attas (Abbas, 2010). Islamisasi pengetahuan tersebut berupaya menyatukan antara sains (pengetahuan) dengan agama dimana maraknya terjadi fenomena pengetahuan yang memisahkan agama dalam kancah kehidupan manusia atau sekularistik.

Ajaran Islam mempunyai visi membawa kebaikan atau rahmat (kebermanfaatan) untuk semesta alam. Ia mengatur semua aspek dimana manusia beraktifitas. Kehadiran Islam dalam riset akuntansi geliatnya mulai muncul ketika Gambling and Karim (1986) memposisikan Islam sebagai bagian dari perubahan sosiologi akuntansi. Islam disoroti sebagai dampak atas pertumbuhan populasi kaum muslim yang kukuh mengimplementasikan ajarannya dalam kehidupan sehari-hari secara individual hingga komunitas. Komunitas muslim tersebut membawa ajaran Islam dalam kegiatan ekonomi mereka yang mengejawantah dalam bentuk lembaga keuangan Islam. Lembaga keuangan Islam inilah yang dianggap mengawinkan Islam dan akuntansi dengan memasukkan atribut zakat sebagai kewajiban pemeluk Islam dan memastikan kegiatan keuangan mereka bebas dari unsur riba. Penalaran tersebut membuat Gambling and Karim (1986) menampilkan alur pemikiran ajaran Islam dalam kegiatan ekonomi dengan meletakkannya sebagai bagian dari akuntansi sosial.

Kajian tentang prinsip Islam dalam penelitian akuntansi dilanjutkan dengan sampling lembaga keuangan yang ada di Negara muslim daerah Timur Tengah seperti di Mesir dan Sudan (Tomkins \& Karim, 1987) yang tumbuh masif sebagai dampak booming harga minyak dunia. Lembaga keuangan di negara-negara tersebut mempunyai konsep yang berbeda dengan lembaga keuangan yang dibawa dari Barat seperti terlarangnya transaksi bunga (riba). Tomkins and Karim (1987) mengungkapkan alasan dilarangnya praktik ribawi di lembaga keuangan Islam, bukan hanya dari sisi keyakinan, namun juga dianalisis dari perspektif sosial yang berdampak pada sikap spekulasi dan penimbunan kekayaan yang merupakan muara dari kegiatan transaksi keuangan yang berbasis riba (Kamla \& Alsoufi, 2015).

Semenjak tahun 80an, mulai bermunculan perhatian peneliti terhadap Islam dan akuntansi dan yang sering dijadikan acuan sebagai empirisnya adalah institusi perbankan Islam di komunitas muslim yang sedang marak ketika itu (Haniffa \& Hudaib, 2010; Napier, 2009). Pendekatan para peneliti tersebut terhadap temuannya kebanyakan bersifat deskriptif dan normatif khas positivisme atas praktik di lembaga keuangan Islam. Pendekatan yang lain masih terbatas dan kebanyakan masih

\footnotetext{
${ }^{1}$ Perusahaan publik $=$ perusahaan yang terdaftar di Bursa Efek Indonesia
} 
memandang Islam sebagai objek yang diteliti pada situs mereka. Mereka ingin mencari benang merah antara prinsip Islam dalam muamalah keuangan Islam dengan prinsip akuntansi yang sudah mapan dari peradaban Barat. Di antaranya ada yang mencoba menelaah lebih dengan pendekatan kepustakaan tentang muasal akuntansi dalam sejarah peradaban Islam bahkan secara bahasa Arab (Lubis, 2015) yang bermuara pada ketidaktegasan tabir antara akuntansi dan muamalah Islam. Peneliti lainnya terus berupaya mengangkat keunggulan yang ada dalam praktik lembaga keuangan Islam dengan mengklaim sebagai akuntansi Islam dan sebagian memfokuskan pada aspek zakat (Ikhsan \& Suwarno, 2003; Kamla \& G. Rammal, 2013), etika bisnis Islam (Haniffa \& Hudaib, 2007; Ladewi, 2014) atau pelaporan yang berdimensi sosial dan lingkungan (Kamla \& G. Rammal, 2013; Othman \& Thani, 2010).

Hal tersebut merupakan sekelumit fakta praktik akuntansi di lembaga keuangan Islam yang menjadi perhatian dan magnet bagi para peneliti akuntansi. Penelitian mereka menggiring kepada penisbatan terminologi akuntansi Islam atau akuntansi syariah yang pada aspek tertentu masih berkesesuaian dengan prinsip Islam (Lubis, 2015). Fenomena tersebut ada benarnya jika dilihat dari kacamata sosiolog bahwa kehadiran akuntansi Islam hanya dikarenakan adanya sekelompok umat muslim yang menyesuaikan aktifitas interaksi bisnis mereka dengan ajaran Islam. Riset tersebut bila dicermati dari pendekatan yang mereka lakukan ternyata masih cenderung menggunakan pendekatan fungsional atau paradigma positivistik/mainstream (Chua, 1986; Hartono, 2016). Pendekatan tersebut begitu popular dan selalu digunakan untuk menjudge semua fenomena akuntansi dan turunannya yang diteliti termasuk akuntansi Islam atau akuntansi syariah.

Beberapa pendekatan bisa digunakan peneliti selain pendekatan tersebut di atas seperti interpretif, kritis, posmo dan spiritualis. Pendekatan dalam sebuah penelitian erat kaitannya dengan paradigma sebagai sebuah cara pandang. Sebagai sebuah fenomena sosial, akuntansi sejatinya merupakan salah satu cabang dari ilmu ekonomi yang berada dalam ranah ilmu pengetahuan sosial. Melihat asal muasalnya, penelitian akuntansi pun harusnya mengikuti pendekatan di bidang sosial dan tidak terjebak dalam satu paradigma tertentu yang bisa mengantarkan pada penelitian yang bersifat pragmatisme atau pandangan konvensional ${ }^{2}$ atas fenomena akuntansi (Djamhuri, 2011). Beranjak dari hal tersebut, tulisan ini mencoba menghadirkan paradigma lainnya yang lebih bersifat khusus dan bisa mengantarkan Islam sebagai paradigma pada riset akuntansi.

Kehadiran Islam sebagai sebuah paradigma dilatarbelakangi oleh definisi sederhana dari kata paradigma yang dimaknai sebagai pandangan dunia (worldview). Definisi paradigma tersebut berisi sekumpulan asumsi atau konsepsi tentang dunia berikut kehidupannya yang sarat dengan nilai kultural, relijius maupun scientific (Mulawarman, 2010). Pembatasan paradigma sebagai pandangan dunia dan kehidupan ini menjadi karakter pandangan Barat yang menekankan hanya pada aspek kehidupan fisik semata. Hal tersebut menjadi celah adanya pandangan yang tidak membatasi pada kehidupan dunia saja, seperti Islam yang cara pandangnya mempunyai spektrum yang lebih luas (tidak hanya realitas keduniaan, namun juga keakhiratan) dan berkorelasi kuat antar spektrum tersebut (Zarkasyi, 2013). Beranjak dari cara pandang tersebut, penelitian akuntansi yang selama ini masih terperangkap dengan paradigma yang bersifat fisikis semata dengan penekanan pada aspek keuangan, dan laba yang bersifat kebendaan/materialistik. Ada beberapa yang mewarnainya dengan nilai-nilai kultural maupun relijius namun belum terjadinya penyatuan yang utuh atas aktifitas tersebut dengan nilai-nilai yang bersifat melampaui kehidupan dunia.

\section{METODE}

Secara umum metode penelitian yang sering digunakan adalah penelitian lapangan dan penelitian kepustakaan. Penelitian lapangan lebih menekankan pada

2 Pandangan konvensional cenderung menyeragamkan penelitian akuntansi dengan paradigma fungsionalis. 
temuan empiris atas praktek yang terjadi sehingga bisa memprediksi dan mengeneralisasi fenomena yang ada. Adapun penelitian kepustakaan lebih bersifat analisis atas hasil-hasil riset terdahulu dengan mengedepankan tawaran konsep atas fenomena yang menjadi objek penelitian. Tulisan ini menggunakan metode kualitatif kajian kepustakaan yang memfokuskan pada pengumpulan beberapa tulisan (yang dilakukan berdasarkan karya tertulis) tentang Islam sebagai paradigma pada penelitian sosial dan akuntansi. Istilah kajian kepustakaan biasanya digunakan pada jenis penelitian yang metode pencarian datanya mengandalkan atau bersumber dari karya tulisan yang diamati secara mendalam terhadap tema tertentu yang menjadi fokusnya. Dengan metode tersebut diharapkan tulisan ini mampu melahir sebuah konsep yang memfasilitasi penelitian-penelitian akuntansi dengan paradigma Islam.

\section{HASIL DAN PEMBAHASAN}

Riset akuntansi telah berkembang dengan ragam paradigmanya dan proses tersebut juga terjadi pada riset yang mengambil situs pada lembaga keuangan Islam atau situs situs Islam lainnya. Perkembangan tersebut tidak luput dari peran para peneliti yang rela berjibaku dengan lingkungan dan sejumlah pemikiran yang terbentuk dan membentuk realita akuntansi. Realita akuntansi dewasa ini seakan masih digiring oleh kuasa paradigma mainstream yang secara ontologi memandang realita sebagai sesuatu yang objektif, berdiri independen di luar diri manusia (Burrel \& Morgan, 2006; Chua, 1986) Di antara ragam paradigma tersebut, paradigma fungsionalis (positivis)lah yang selalu dilakukan dan dipilih oleh para peneliti di bidang akuntansi. Seolah ada consensus tak tertulis bahwa, paradigma tersebut menjadi standard dan dinilai objektif serta selalu menjadi alat untuk mengeneralisasi setiap temuannya sebagai perkuatan atau mendukung atas hipotesis atau teori yang sudah ada. Hal ini tentunya merupakan sebuah ketimpangan dalam perpektif yang lain dimana ada arogansi atau dominasi atas sebuah paradigma atas paradigma lain dalam penelitian sosial. Berikut akan diuraikan tentang ragam paradigma tersebut.

Paradigma yang dominan dalam pengembangan ilmu pengetahuan adalah paradigma fungsionalis, karenanya sering diberi julukan sebagai paradigma mainstream (Chua, 1986). Secara ontologi, paradigma ini banyak dipengaruhi oleh realisme fisik yang memandang realitas sosial sebagai sesuatu yang obyektif, berdiri secara independen di luar diri manusia (Burrel \& Morgan, 2006; Chua, 1986). Realitas sosial dipandang sebagai sesuatu yang given, berada di luar dirinya (out there), secara konkrit (bisa dipahami dengan panca indra) dapat diketahui, dan orang tersebut tidak ikut serta dalam proses tersebut. Hal inilah yang menjadikannya seolah bebas nilai atau value-free. Penelitian dengan paradigma ini selalu menekankan aspek empirisme dengan obyektivitas yang tinggi dan adanya pengukuran-pengukuran akurat - melalui sebuah instrumen yang dinamakan questionnaire - terhadap realitas sosial yang ditelitinya. Sederhanan realitas sosial mempunyai hukum universal di mana peneliti berkepentingan untuk menemukan atau mengungkapkannya. Dengan pandangan tersebut, ilmu pengetahuan menurut mereka bersifat deduktif (sering menggunakan hypothetico-deductive approach) dan bersifat nomotetis yang mengandung hukum sebab-akibat yang universal (Sarantakos, 2012).

Paradigma berikutnya adalah interpretif yang lebih menekankan pada aspek peranan bahasa, interpretasi, dan pemahaman (Chua 1969). Paradigma ini menggunakan cara pandang para nominalis dari paham nominalism yang melihat realitas sosial sebagai sesuatu yang tidak lain adalah label, nama, atau konsep yang digunakan untuk membangun realitas (Burrell \& Morgan, 1979; Hartono, 2016). Paradigma ini memandang manusia (peneliti) sebagai mahluk yang aktif dalam menciptakan realitas sosial atau dunianya sendiri melalui pemberian sistem makna dan tidak ada hukum universal dari lingkungan tertentu sehingga yang ada hanyalah makna-makna subyektif, pola dan keteraturan perilaku yang timbul sebagai akibat dari konvensi sosial yang diperoleh dari proses interaksi sosial (Sarantakos 2012). Paradigma ini menggunakan inductive approach, yaitu dari sesuatu yang khusus ke yang umum atau dari sesuatu yang konkrit ke yang abstrak dengan menggunakan proses pemaknaan yang tidak sekedar menggunakan indra, namun juga pemahaman 
makna dan interpretasi yang lebih dipentingkan dari realitas sosial yang sedang diteliti.

Realitas sosial yang diciptakan oleh manusia (melalui interaksi sosial) berikut sistem maknanya, menjadikan ilmu pengetahuan menurut paradigma ini tidak bebas dari nilai alias value laden (sarat nilai). Sehingga paradigma ini menganggap ilmu pengetahuan bersifat ideographic (tidak menunjukkan hukum universal, hanya realitas simbolik yang disajikan secara deskriptif dalam ungkapan bahasa), bukan nomothetic (Sarantakos 2012). Ilmu pengetahuan yang diperoleh dalam penelitian dengan paradigma ini bertujuan memberikan makna (to interpret) dan memahami (to understand) realitas sosial dan proses terjaadinya atau alasan mengapa sebuah kegiatan dilakukan oleh seseorang. Penelitian yang dilakukan bertujuan memahami bagaimana manusia membangun sendiri kehidupannya dan memberikan makna terhadap kehidupan tersebut serta berupaya untuk memahami konteks sosial dari sebuah tindakan (Sarantakos, 2012; Triyuwono, 2011).

Paradigma lainnya adalah paradigma kritis, yang sebenarnya merupakan lompatan dari paradigma interpretif yang terkesan masih anggun dalam melihat fenomena yang diteliti. Paradigma ini tidak mau mencukupkan diri hanya pada menginterpretasikan sebuah realitas sosial, namun ia bersifat konstruktif alias memberikan tawaran akan perubahan atas realitas tersebut. Paradigma ini melihat realitas sosial tidaklah diciptakan oleh alam, namun diciptakan oleh manusia yang berkuasa memanipulasi, mengkondisikan, dan mencuci-otak (brain-wash) orang lain agar memahami atau menginterpretasikan sesuatu sesuai dengan interpretasi yang diinginkan oleh yang berkuasa tersebut (Triyuwono, 2011). Realitas sosial dicirikan dengan sebuah tatanan yang selalu dalam konflik, tekanan, dan kontradiksi yang dihasilkan oleh dunia (keadaan) yang selalu berubah dan penampakannya berdasarkan pada ilusi dan distorsi (Sarantakos 2012).

Perhatian utama pada paradigma kritis adalah membuka mitos dan ilusi, mengekspos struktur yang nyata, dan mempresentasikan realitas sebagaimana adanya (as it is) dengan manusia sebagai mahluk yang memiliki potensi yang besar untuk berkreasi dan melakukan penyesuaian (Sarantakos, 2012; Triyuwono, 2011). Paradigm ini memposisikan ilmu pengetahuan berada di antara positivisme dan interpretive social science; atau di antara determinisme dan humanisme. Kondisi sosial ekonomi yang membentuk realitas sosial mengkonfrontasi manusia agar mereka mampu memberikan makna atas dunianya dan melakukan tindakan berdasarkan makna itu untuk melakukan perubahan. Menurut mereka, ilmu pengetahuan tidak sekedar sarat nilai, namun para theorist dan peneliti melakukan aksi berdasarkan pada penelitian atau teori yang mereka hasilkan melalui penelitiannya (Sarantakos, 2012; Triyuwono, 2011). Sehingga penelitian dalam paradigma ini bertujuan "menjelaskan tatanan sosial, sehingga penelitian ini menjadi katalis dalam transformasi tatanan sosial" atau menjelaskan dan mengkritik realitas sosial dan memberdayakan manusia untuk menaklukkannya (Fay, 1987; Sarantakos, 2012), untuk memahami dan merubah realitas sosial (Lather, 1992; Sarantakos, 2012).

Berikutnya adalah paradigma postmodern yang memiliki keaneka-ragaman pemikiran di dalamnya yang bisa meliputi Marxisme Barat, strukturalisme Prancis, nihilisme, etnometodogi, romantisisme, populisme, dan hermeneutika" (Hadiwinata 1994, 31). Keanekaragaman pemikiran tersebutlah yang membuat paradigma posmodernisme dianggap tidak mempunyai "bentuk" yang jelas. Namun bila kita menilik dari kacamata lain, tidak adanya bentuk dalam posmodernisme ini lah yang sebenarnya merupakan "bentuk" asli dari postmodern itu sendiri. Posmodernisme mempunyai karakter utama yang terletak pada usaha dekonstruksi yang dilakukan terhadap semua bentuk "logosentrisme" yang dibuat oleh modernisme (paradigma fungsionalis). Dekonstruksi yang dilakukan posmodernisme dengan memasukkan "sang lain" yang dimarginalkan, disepelekan, ditindas, dieksploitasi, dan di"bunuh" ke dalam kedudukan yang sama dengan apa yang dilogosentriskan oleh modernisme (Triyuwono, 2011).

Paradigma posmodernisme menurut Triyuwono (2011) tidak menafikan adanya realitas lain seperti psikis, spiritual, sifat Tuhan (asma' sifatiyah), dan realitas 
absolut/Tuhan (Bakar, 1994; Nasr, 1993) selain realitas materi dalam kehidupan manusia, dan ini berseberangan dengan peradigma modernisme dimana realitas materi dianggap realitas sentral dan tunggal. Semua realitas tersebut sama pentingnya dengan realitas materi dan sebagai satu kesatuan yang tidak dapat dipisahkan. Posmodernisme memahami manusia dapat mengkonstruk ilmu pengetahuan dengan unsur akal, mental, dan spiritualnya dan ini merupakan konsekuensi dari posmodernisme yang memahami kehidupan sehari-hari sebagai kehidupan yang intuitif, menggunakan perasaan (feeling), dan bersifat spiritual (Rosenau, 1992). Paradigma ini menganggap ilmu pengetahuan bersifat tidak sistematis, memiliki logika yang sifatnya cukup majemuk, tidak berpusat, selalu berubah/berkembang, dan bersifat lokal (Rosenau, 1992). Ilmu pengetahuan dikonstruk paradigma untuk melihat dan mengungkapkan realitas sosial sebagaimana "adanya" menurut pemahaman masyarakat (subyek yang menciptakan realitas sosial) dan diungkapkan oleh subyek peneliti dalam konteks sosial, budaya, dan berpikir masyarakat di mana realitas tadi tercipta dan dipraktikkan tanpa struktur formalitas ilmiah seperti yang ada pada positivisme (Rosenau 1992, 117). Realitas sosial dipahami bersamaan dengan realitas lainnya yang bersifat lokal (local) dan sarat nilai (value laden), meskipun tidak menutup kemungkinan mengandung nilai atau hukum universal (Triyuwono, 2011).

Beranjak dari paradigma postmodernisme, paradigma spiritualitas lahir dengan mengakui adanya realitas lain (selain realitas fisik) dan realitas lain tersebut sejatinya adalah realitas absolut (Tuhan). Tuhan adalah satu-satunya realitas sedang realitas lainnya hanyalah bagian dari diriNya (Triyuwono, 2011). Paradigma ini memahami bahwa di balik segala sesuatu yang tampak fisikal, di situ ada Tuhan yang meliputi segala sesuatu di alam semesta dalam satu kesatuan yang tidak bisa dipisahkan sama sekali atau bertajalli (Triyuwono, 2011; Bahri, 2011). Paradigma ini memposisikan manusia sebagai pengejawantahan Tuhan dengan cahaya Ilahi dan usaha manusia dalam melakukan penelitian (untuk menemukan ilmu) sejatinya bertujuan membangkitkan kesadaran Ketuhanan (Triyuwono, 2008). Paradigma ini sepertinya menjadi iconic yang muncul di lingkungan school of thought-nya Universitas Brawijaya. Paradigma spiritualisme inilah yang sering digadang-gadang sebagai pendekatan yang dominan dijadikan pijakan bagi riset akuntansi dan Islam, walau pernyataan tersebut perlu penelusuran dan analisis lebih.

Arogansi Sebuah Paradigma. Melihat ciri khas dan masing-masing karakter kelima paradigma tersebut, bisa disimpulkan bahwa masing-masing mempunyai keunikan tersendiri dalam mendapatkan ilmu pengetahuan atau mengembangkan sebuah teori. Sehingga tidaklah tepat dan gegabah jika ada yang mengklaim bahwa sebuah pengembangan teori atau ilmu pengetahuan mutlak dengan jalan empiris ala paradigma positivis. Ketidaklayakkan klaim tersebut juga sebenarnya bisa kita lihat dalam realitas yang melingkupi manusia sebagai makhluk sosial yang setiap interaksinya terkait erat dengan ilmu sosiologi, antropologi dan psikologi. Ada realitas lainnya (seperti yang dijelaskan oleh paradigma posmodernisme) yang bisa jadi tidak bisa dikuantitatifkan atau dibuatkan model empiricalnya, namun keberadaannya bisa ditemukan dan dirasakan. Hal ini tentunya juga sebuah pengetahuan yang bisa diperoleh tanpa harus dilatarbelakangi oleh sebuah teori atau asumsi apapun. Bahkan dalam paradigma spiritualisme (tepatnya Islam), ada sebuah pemahaman bahwa segala sumber pengetahuan itu adalah dari Tuhan. Artinya, manusia tiada mampu menemukan sebuah ilmu pengetahuan tanpa adanya sebuah alat yang diberikan oleh Tuhan untuk menemukan ilmu pengetahuan itu yakni akal.

Mengarus utamanya sebuah paradigma yang ada di ranah penelitian akuntansi, sepertinya perlu dicermati dari kacamata yang lebih dalam dan integral. Bila kita mencermati maraknya pengadopsian standar akuntansi keuangan Indonesia ke IFRS, bisa dilihat dari perspektif social Darwinism. Pengadopsian IFRS di Indonesia dan beberapa Negara di dunia dewasa ini merupakan metafora konsep Darwinisme tentang natural selection. Implikasi seleksi alam tersebut mengantarkan pada persaingan dan adanya paradigma untuk terus bersaing dan menguasai atau mendominasi. Untuk bisa menguasai dan mendominasi pada akhirnya, manusia 
yang satu menjadi saingan bagi manusia yang lainnya. Artinya metafora seleksi alam tersebut sudah merangsek ke bidang sosial, termasuk akuntansi. Demikian juga dengan fenomena, pengadopsian IFRS, standar akuntansi Indonesia dulunya merujuk ke standar yang ada di AS (Triyuwono, Sukoharsono, \& Djamhuri, 2015). Namun seiring dengan persaingan antar standard setting internasional, Indonesia terpikat dan terjerat dengan standar IFRS yang notebenenya adalah kolonialisme gaya baru dengan jalan menjadi anggota dari Negara-negara G20 (Hamidah, 2013). Dan jika dicermati, pengadopsian hampir sebagian besar Negara di dunia ke IFRS merupakan sebuah seleksi alam dimana yang kuat dan bisa mempengaruhi para pengambil kebijakan di setiap negara, maka ia yang akan menang.

Kemenangan adopsi tersebut semakin menancapkan pilihan para peneliti pragmatis dengan paradigma fungsionalis pada penelitian akuntansi. Paradigma ini dengan semua ciri khas dan model pengukurannya seolah menjadi satu satu jalan untuk menemukan sebuah pengetahuan baru. Paradigma ini mengklaim bahwa sebuah pengetahuan haruslah bisa diobservasi dan bersifat empiris. Jika tidak bisa diobservasi (secara inderawi) dan empiris, maka sesuatu yang diteliti tersebut tidak bisa disebut sebagai sebuah pengetahuan. Padahal bila dicermati, paradigma ini seakan berjalan di tempat karena terjebak dan kurang inovatif dengan teori dan hipotesis-hipotesis yang telah ada terdahulu, tanpa adanya inovasi akan fenomena yang terus berkembang di setiap masing-masing karakter wilayah atau lokalitas. Hal tersebut menunjukkan bahwa penelitian akuntansi (dengan paradigma fungsionalis) mempunyai pola tertentu, stagnan dan mudah ditebak hasilnya (Utama, 2016). Paradigma ini tidak lama lagi, mau tidak mau harus berposisi yang sejajar dengan paradigma lainnya agar penemuan-penemuan dan inovasi atas pengetahuan yang baru bisa lebih beragam dan mempunyai keunikan tersendiri yang tidak menutup kemungkinan untuk diintegrasikan secara menyeluruh.

Demikian juga dengan riset akuntansi Islam, sedari awal ketenaran pembahasannya, pendekatan yang digunakan masih dominan dengan pendekatan fungsionalis walau ada beberapa yang seolah lepas dari paradigma positifis namun jika ditelaah dengan lebih seksama akan menjumpai keaslian paradigma yang sebenarnya. Sejak tahun 1980an bermunculan pemikiran tentang akuntansi Islam yang merujuk pada implementasi ajaran Islam dalam kegiatan atau lembaga keuangan Islam (Maali \& Napier, 2010) seperti Gambling dan Karim

Adakah Paradigma Selanjutnya?. Kesemua paradigma di atas, sebenarnya adalah sebuah karya akal manusia dalam memahami realitas yang ada di sekitar mereka dengan tujuan agar menemukan sebuah hipotesis atau teori atas realitas tersebut. Atau bisa juga disederhanakan sebagai proses mencari pengetahuan yang tersebar di seluruh penjuru dunia. Pengklasifikasian ragam paradigma tersebut tdak luput dari konsep yang ada dalam benak para penggagasnya. Rata-rata mereka mendasari klasifikasi tersebut atas fenomena masyarakat dan apa yang masyarakat "pegang" dalam menjalankan aktivitas yang menciptakan realita sosial. Bagi sebagian besar pada peneliti, kemunculan paradigma spiritualitas bisa jadi merupakan sebuah simpulan dan penyederhanaan yang mereka lakukan dengan dasar bahwa yang menjadi mind sets dalam paradigma ini adalah spirit. Spirit yang dimaksud disini seolah sudah melampaui fisik, akal dan kejiwaan. Ajaran atau pemikiran yang bisa menjangkau level spiritualitas ini kebanyakan ditemukan dalam school of thought (ajaran) keagamaan atau keyakinan, sehingga baik perspektif Islam, Nasrani maupun Yahudi atau agama lainnya dikelompokkan ke dalam paradigma spiritualitas.

Islam adalah sebuah agama yang dibawa oleh Muhammad yang mengajak manusia untuk menEsakan Tuhan beserta mengamalkan semua perintahNya dalam menjalani kehidupan dunia. Islam mempunyai seperangkat ide dan sumber ide dasarnya berasal dari Al Quran yang notabene nya adalah kalamullah atau perkataan Allah dan Sunnah Rasulullah. Al Quran berisi petunjuk bagi manusia dalam menjalani kehidupan dunia, dan bertujuan agar manusia mencapai kesadaran yang tertinggi yakni khalifah fil ardhi sebagai pengampu amanah Allah dimuka bumi (Bustami, 2016; Hasanah, 2009; Triyuwono, 2015). Sunnah rasul berisi metode dan 
tata cara implemetasi praktis perbuatan manusia yang menjelaskan lebih detail, bahkan adanya peluang inovasi dalam hal-hal tertentu (non ritual).

Paradigma Islam sejak kemunculannya di Mekkah, telah menyadarkan manusia bahwa ketundukkan mereka hanyalah kepada sang Pencipta. Islam mengajak manusia mengoptimalkan potensi yang diberikan Tuhan baik berupa fisik dan terlebih akalnya sebagai pembeda dengan makhluk Allah yang lainnya. Pengoptimalan akal ini sejatinya bisa menghantarkan manusia ke derajat kesadaran yang tinggi atau kesadaran Ilahiah. Sebuah kesadaran yang memposisikan diri manusia sebagai hamba Allah yang terikat dengan system aturan yang telah diberikanNya untuk mencapai derajat khalifah fil ardh.

Islam sebagai sebuah paradigma mempunyai keunikan dari aspek bahwa semua pengetahuan dalam Islam bersumber dari Tuhan ${ }^{3}$. Artinya, Tuhan sudah memberikan rambu-rambu dan juga seabrek informasi terkait dengan hal-hal yang telah lalu (bisa dibaca tentang beberapa kaum sebelum datangnya Islam) atau informasi yang akan datang (terkait kiamat dan kerusakan kehidupan bila ada aturanNya yang diabaikan/dilanggar). Al Quran telah menyampaikan tentang beberapa contoh umat manusia yang abai akan aturan Tuhan (baik karena tidak menEsakan Tuhan atau melakukan perbuatan yang rusak) dan bekas keberadaan mereka bisa ditemukan/buktikan. Ini mengindikasikan isi dari Al Quran tidak bertentangan dengan realitas yang ada. Adapun tentang hal yang futuristic, Islam (Al Quran) juga menyampaikan terkait akan munculnya kerusakan di bumi yang penyebabnya adalah karena ulah tangan manusia yang tidak cakap pada surah Ar Rum ayat 41 yang artinya sebagai berikut:

"Telah Nampak kerusakan di darat dan di laut disebabkan karena perbuatan tangan manusia, supaya Allah merasakan kepada mereka sebahagian dari (akibat) perbuatan mereka, agar mereka kembali (ke jalan yang benar)"

Berdasarkan uraian singkat tentang Islam tersebut dan apa saja yang diliputi oleh ajaran ini, maka sebenarnya bisa disimpulkan sebuah kaidah umum bahwa manusia dalam menjalankan seluruh kehidupannya haruslah selalu merujuk pada aturan (syariat) Islam. Termasuk dalam aspek kegiatan akuntansi, Islam juga sudah membuat rambu-rambu umum akan perkara akuntansi ini sehingga dalam pengembangan pengetahuan atas akuntansi juga sewajarnya merujuk kepada apaapa yang Islam telah gariskan. Sehingga tidak aneh ketika awal kehadiran intistusi keuangan Islam, mereka sangat memperhatikan rambu-rambu umum yang Islam atur atas kegiatan ekonomi(Dima, David, \& Păiuşan, 2010)

Paradigma Islam dalam Riset Akuntansi. Masuknya paradigma Islam dalam perkembangan keilmuan, tidak bisa dipungkiri bermula dari maraknya proses Islamisasi ilmu pengetahuan yang disinyalir merupakan counter attack atas terjadinya sekulerisme ilmu pengetahuan (Kuntowijoyo, 2008). Sekulerisme ilmu pengetahuan ini ditengarai disebabkan adanya kebablasan para peneliti akan fenomena alami modernsme filsafat sehingga menuju pada titik pengagungan rasio manusia dan meniadakan peran Tuhan di dalamnya (Bisryi, 2013). Para ilmuwan Barat membatasi ilmu pengetahuan hanya pada hal-hal yang bisa diindera saja (salah satu ciri paradigma positivisme yang empirical atau dapat diobservasi. Mereka meragukan keilmiahan dari ilmu-ilmu yang menjadikan objeknya bersifat nonempiris yang tidak bisa diobservasi dan dibuktikan secara empiris atau inderawi (Kartanegara, 2007). $\mathrm{Hal}$ tersebut tentunya berbeda dengan para ilmuwan muslim yang menurut mereka dalam mencari ilmu pengetahuan tidaklah hanya pada hal yang bersifat inderawi namun juga hal-hal yang bersifat substansi-substansi spiritual.

Sebenarnya bila kita mempelajari Islam dengan utuh, tidaklah perlu munculnya sebuah proses Islamisasi ilmu pengetahuan. Adanya sikap reaktif di atas bisa jadi

3 Pengetahuan ini bisa bersifat umum seperti yang disampaikan Allah berikut: "Kepunyaan Allah-lah apa yang ada di langit dan apa yang ada di bumi, dan adalah (pengetahuan) Allah maha meliputi segala sesuatu" (terjemah QS. An Nisa; 126) 
karena para ilmuwan Barat yang masih bersikukuh dengan paradigma fungsionalisnya, sehingga hal-hal seperti agama tidak (berani) dijamah. Padahal tanpa adanya pengakuan dari para ilmuwan tersebut pun, Islam tetaplah menjadi rujukan bagi pemeluknya untuk berparadigma dalam setiap aspek kehidupannya dan hal inilah yang menjadikan Islam sebagai sebuah paradigma yang terbuka (Kuntowijoyo, 2008, hal. 485).

Digunakannya terminologi paradigma Islam dalam riset akuntansi, bagi sebagian akan dikelompokkan ke dalam paradigma spiritualitas. Namun penulis ingin memunculkan keunikan dari paradigma Islam ini sebagai sebuah paradigma tersendiri yang tidak terkategorikan sebagai paradigma spiritualitas. Keunikan paradigma Islam ini terletak pada bangunan awal bahwa semua pengetahuan bersumber dari Tuhan, dan Islam sangat menganjurkan agar ummatnya melakukan pengungkapan atas ayat-ayat Allah yang tidak hanya termaktub dalam teks suci Allah (Al Quran), namun tersebar di seluruh jagat alam raya. Hal ini berkesesuaian dengan yang Allah sampaikan pada QS. An Nur ayat 41 di atas dan inilah yang menjadikan setiap adanya hal-hal baru secara alami ditemukan, maka hal tersebut harus digali para ilmuwan terkait makna kontekstual atas fenomena tersebut.

Fenomena inderawi yang bersebaran di alam semesta ini selalu melibatkan aspek alam itu sendiri dan tentunya peran manusia di dalamnya. Terkait dengan peran manusia, Islam telah menggariskan bahwa seluruh perbuatan manusia haruslah menghantarkannya pada sebuah kesadaran Ilahiah, yakni kesadaran akan ketundukan manusia dengan aturanNYA. Dengan adanya kesadaran Ilahiah ini, manusia cenderung untuk selalu memperhatikan aspek tindak tanduk aktivitas mereka dengan apa-apa yang diridhait oleh Allah SWT. Keridhaan Allah bisa ditelusuri dalam ayat-ayat Al Quran yang berisi hal perihal yang manusia harus pikirkan, lakukan dan rasakan.

Islam adalah sebuah pandangan hidup, dimana aturan Islam yang berkaitan dengan bagaimana interaksi (kehidupan) antar manusia layaknya terlaksana telah disebutkan di dalam Al Quran dan Sunah Nabi berikut pembahasan detailnya. Sebagai sebuah pandangan hidup, ia juga mampu merespon semua perkara kehidupan yang dialami manusia hingga akhir zaman. Adapun untuk hal-hal baru yang pada masa Nabi dan sahabat belum dan tidak ditemukan, terbuka peluang bagi para cendikiawan (ulama) untuk melakukan penggalian status atas perkara baru tersebut yang disebut dengan istilah ijtihad.

Sehubungan dengan interaksi antar manusia, Islam telah mengaturnya dalam hukum muamalah. Kegiatan akuntansi dan derivatnya semisal riset akuntansi juga merupakan muamalah yang bias ditelusuri status hukumnya menurut Islam dengan terlebih dahulu melihat fakta dan realita akuntansi itu sendiri. Setelah memperoleh pemahaman akan fakta aktivitas di bidang akuntansi tersebut (berikut tujuan dan dorongan yang melatarbelakangi perbuatan manusia), barulah digali status hukum aktivitas tersebut berdasarkan dalil-dalil syara ${ }^{5}$. Menilik akuntansi dalam kacamata faktual, ia merupakan sebuah kegiatan yang berupaya merangkum rangkaian kejadian ekonomi suatu entitas dalam periode tertentu yang disajikan dalam sebuah laporan keuangan. Rangkaian kejadian ekonomi ini biasanya melibatkan aspek keuangan yang bisa dicermati dan ditelusuri status-status muamalat mereka dalam paradigma Islam, sehingga dapat ditarik sebuah simpulan besar terkait aktivitas akuntansi tersebut.

Menghubungkan akuntansi dengan Islam dari aspek muamalat para pelaku yang terlibat dalam proses akuntansi sudah lama menjadi bahasan para ilmuwan muslim. Hal ini seiring dengan bermunculannya kesadaran mereka akan Islam sebagai sebuah pedoman hidup (tidak hanya sebagai aspek ritual semata) yang membuat mereka melakukan islamisasi ilmu pengetahuan. Hal ini juga terpicu dengan ditengarai pendirian lembaga-lembaga keuangan yang menggunakan prinsip-

4 Disukai oleh Allah SWT yang berkonsekuensi pada pemberian pahala atas perbuatan manusia yang diridhaiNYA.

5 Berupa ayat-ayat dari Al Quran atau hadits Rasul yang berisi atau menggambarkan sebuah perbuatan manusia 
prinsip Islam dalam operasionalisasi kegiatan mereka. Dari sinilah terminologi akuntansi Islam muncul.

Akuntansi Islam (disebut juga akuntansi syariah pada konteks Indonesia) dalam perkembangannya seakan terjebak hanya pada semua kegiatan yang berhubungan dengan lembaga keuangan beserta turunannya (asuransi, maupun pasar modal syariah). Padahal hampir semua kegiatan ekonomi yang secara konvensional ${ }^{6}$ dijalankan para pelaku bisnis merupakan muamalah juga yang perlu dibenahi agar berkesesuaian dengan aturan Islam. Hal ini tidak menutup kemungkinan adanya muamalah batil ${ }^{7}$ yang harus dihilangkan atau diganti dengan muamalah yang sah dalam paradigma Islam.

Berangkat dari fenomena di atas, perlunya paradigma Islam yang dijadikan alat (teropong) dalam rangka mencermati fenomena akuntansi yang sudah beragam bentuknya dan kemungkinan adanya temuan-temuan atas kegiatan masyarakat lokal di sekitar kita yang bisa jadi di dalamnya sudah terinternalisasi muamalahmuamalah yang berprinsip pada ajaran Islam yang layak diakuntansikan. Indonesia dengan kultur dan ajaran Islamnya telah banyak mempunyai fenomena sosial yang sarat dengan nilai-nilai Islam. Nilai-nilai Islam tersebut menjadi prinsip masyarakat Indonesia dalam menjalankan aktivitas mereka dan hal ini terejawantahkan dalam komunitas-komunitas bisnis lokal. Hanif (2014) menemukan tentang akuntansi sistem mato pada restoran/rumah makan Padang yang mengungkapkan bahwa muamalah yang mereka (pengelola restoran) lakukan selama ini ternyata merujuk pada prinsip-prinsip Islam. Alimuddin (2011) yang menemukan adanya pencapaian mashlahah melalui penerapan nilai-nilai Islam dalam menjalankan kegiatan ekonomi dan bisnis. Niswatin (2014) juga membawa paradigma interpretif Islam dengan melakukan pemurnian pada fenomenologi interpretif melalui mentauhidkan Tuhan sebagai pencipta realitas dan memposisikan wahyuNya sebagai pelengkap realita empiris.

Sebenarnya yang menjadi fokus dalam paradigma Islam atas fenomena penelitian akuntansi adalah realitas sosial yang ada di tengah masyarakat muslim yang bisa dieksploitasi dengan dalam sampai pada tingkat kesadaran terdalam para informan dan situs yang diteliti. Untuk mendapatkan temuan tersebut beberapa paradigma yang dijelaskan di atas sebenarnya bisa saja digunakan dalam menangkap fenomena akuntansi. Bahkan tidak menutup kemungkinan terungkapnya kegiatankegiatan akuntansi lokal yang sarat dengan nilai-nilai Islam seperti pada beberapa penelitian yang disebutkan pada contoh di atas.

Mencermati perkembangan akuntansi keuangan syariah yang marak dewasa ini dan kebanyakan lebih terkumpul pada kegiatan sector keuangan, sepertinya juga menarik untuk disorot dengan paradigma Islam. Fenomena selama ini yang diteliti dan diungkapkan hanya sebatas pada fenomena kulit sebuah realitas social yang menjalankan kegiatan muamalah mereka dalam bidang akuntansi keuangan. Paradigma yang sering dipakai pun masih didominasi oleh paradigma fungsionalis empiris, masih terbilang sedikit yang menggunakan pendekatan atau paradigma nonmainstream untuk memotret dan menggali fenomena muamalah (bisnis) keuangan syariah tersebut. Dengan paradigma Islam, hal pertama yang nantinya akan dicermati terlebih dahulu adalah penangkapan fenomena/fakta realitas muamalah tersebut, yang dilanjutkan dengan pencarian literature atau sumber-sumber hukum Islam yang berkenaan dengan muamalah yang ada.

Dalam menangkap fenomena akuntansi yang ada, peneliti bisa saja menggunakan metode-metode yang berafiliasi dengan paradigma tertentu semisal interpretif, kritis, postmodern atau spiritualitas. Dengan adanya keleluasaan metode yang nantinya digunakan, ini akan memperjelas gambaran dan realitas yang diteliti itu sendiri. Adapun terkait penggalian literatur-literatur Islam yang bersumber Al Qur'an dan Sunnah, mestilah dilakukan dengan penuh cermatan terkait kaidah di dalamnya. Dalam tahapan ini, ada baiknya peneliti melibatkan para ulama atau

\footnotetext{
${ }^{6}$ Terminologi yang seakan menunjukkan bahwa kegiatan ini belum mengacu pada prinsip-prinsip Islam.

${ }^{7}$ Cacat atau rusak secara Islam dan mendapatkan dosa bagi pelaku yang menjalankan muamalah model ini.
} 
cendikiawan muslim yang mumpuni di bidang khasanah keIslaman. Ini menjadi penting karena ajaran Islam dalam menginterpretasikan tiap sabda Allah SWT dan RasulNya tidaklah secara bahasa saja, namun juga memperhatikan kontekstual diturunkannya suatu syariat untuk umat manusia. Tidak jarang ditemukan para cendikiawan muslim yang terlalu gegabah dan tergesa-gesa dalam mengambil suatu kesimpulan hukum atas beberapa literatur-literatur Islam.

Setelah memperoleh gambaran fenomena realitas yang ada, dan menggali sumber-sumber literatur Islam yang berkenaan dengan realitas yang diteliti, tahapan selanjutnya adalah mempertemukan dan mengkonfirmasi kesesuaian fakta dengan dalil/sumber literatur Islam. Hal ini dilakukan semata agar bisa menarik simpulan atas realitas yang diteliti dan kesesuaiannya dengan aturan (syariat) Islam. Apabila ditemukan adanya kebertentangan antara fakta/fenomena yang diteliti dengan seruan yang ada dalam nash-nash syara, disinilah peran para peneliti sebagai cendikiawan muslim untuk memberikan solusi terhadap fenomena tersebut. Pemberian sokusi atau masukan dalam penelitian ini semata-mata bertujuan agar setiap perbuatan manusia (peneliti) tidaklah terbuang percuma, namun memberikan kontribusi aplikatif dalam muamalah di tengah kaum muslim.

Singkatnya, paradigma Islam dalam penelitian akuntansi Islam nantinya bertujuan menggambarkan realitas akuntansi, sekaligus memberikan status atas realitas tersebut dan memberikan solusi terhadap realitas yang diteliti dengan aturan Islam. Tidaklah aneh jika dalam temuannya ternyata ada ditemukan fenomena yang terkesan biasa saja dan ada kemiripan dengan fenomena yang juga terjadi di lingkungan masyarakat non muslim, namun secara hakiki dan filosofi tindakan mereka berkesesuaian dengan nilai dan prinsip-prinsip dalam Islam. Hal inilah yang merupakan sebuah temuan baru akan fenomena Islam yang sejatinya berlatar belakang dengan kultur Islam itu sendiri yang telah lama menyambangi kawasan nusantara ini. Sehingga tidaklah aneh, jika ditemukannya sistem bagi hasil mato dalam restoran Padang seperti yang diteliti Hanif (2014), menghadirkan fenomenologi Islam pada penilaian kinerja Bank syariah (Niswatin, 2014) atau nilai jual mashlahah dalam penelitian Alimuddin (2011) yang kesemuanya bermula pada menggali fenomena yang ada di tengah komunitas muslim yang terkesan hanya menjalankan rutinitas biasa layaknya yang dilakukan juga oleh komunitas di belahan dunia lainnya.

\section{SIMPULAN}

Perkembangan penelitian sosial sudah memasuki kurun yang meniscayakan adanya ekstensi atas ragam paradigma yang tidak hanya diplot atas 4 ranah paradigma (Burrel \& Morgan, 2006). Islam dengan segala ajarannya telah membawa paradigma sendiri yang menjadi pembeda dari paradigma sosial lainnya, walau diawal-awal trend penelitiannya Islam hanya dijadikan "objek" untuk diteliti. Tulisan ini mencoba menguatkan argumentasi bahwa paradigma Islam layak menjadi sebuah paradigma tersendiri untuk digunakan dalam riset akuntansi. Hal ini lahir dari landasan filosofisnya yang membedakan paradigma ini dari paradigma lain yang cenderung sekularistik. Islam hadir bukanlah sebagai sebuah ajaran ritualitas an sich antara manusia dengan Tuhannya, namun ia juga mempunyai seperangakat pedoman yang mengatur bagaimana baiknya manusia berinteraksi dengan sesama manusia dan alam semesta. Adanya pengaturan yang bersifat holistik tersebut menjadi penguat bahwa Islam sebagai sebuah paradigma dalam melihat fenomena kehidupan termasuk riset akuntansi. Allahu'alam

\section{DAFTAR PUSTAKA}

Abbas, A. 2010. Islamisasi Ilmu Pengetahuan. Shautut Tarbiyah, 232(2), 30-39.

Alimuddin. 2011. Konsep Harga Jual Mashlahah Berbasis Nila-nilai Islam. Disertasi, Program Doktor Ilmu Akuntansi FEB Universitas Brawijaya Malang, Malang.

Bisryi, H. 2013. Mengakhiri Dikotomi Ilmu Dalam Dunia Pendidikan. Paper presented at the Forum Tarbiyah.

Burrel, G., \& Morgan, G. 2006. Sociological paradigms and organizational analysis. 
Burrell, G., \& Morgan, G. 1979. Social paradigms and organizational analysis: Elements of the sociology of corporate life: London: Heinemann Educational.

Bustami, Y. 2016. Studi Penerapan Nilai-Nilai Syarah Pada Pelaksana Lembaga Keuangan Syariah (Studi Pada BMT Serambi Madinah). Al-Qisthu, 14(2).

Cahyonowati, N., \& Ratmono, D. 2012. Adopsi IFRS dan Relevansi Nilai Informasi Akuntansi. Jurnal Akuntansi dan Keuangan, 14(2), 105-115.

Chua, W. F. 1986. Radical developments in accounting thought. Accounting review, 601-632.

Dima, S. M., David, D., \& Păiuşan, L. 2010. Specific features of Islamic accounting and cultural paradigm: Munich Personal RePEc Archive.

Djamhuri, A. 2011. Ilmu Pengetahuan Sosial dan Berbagai Paradigma dalam Kajian Akuntansi. Jurnal Akuntansi Multiparadigma, 2(1), 147-185.

Fay, B. 1987. Critical social science: Liberation and its limits. New York: Cornell UP.

Gambling, T. E., \& Karim, R. A. A. 1986. Islam and 'Social accounting'. Journal of Business Finance \& Accounting, 13(1), 39-50.

Hamidah, H. 2013. Adoption Of International Financial Reporting Standards (IFRS) In Indonesia. Journal of Economics, Business \& Accountancy Ventura, 16(2).

Haniffa, R., \& Hudaib, M. 2007. Exploring the ethical identity of Islamic banks via communication in annual reports. Journal of Business Ethics, 76(1), 97-116.

Haniffa, R., \& Hudaib, M. 2010. The two Ws of Islamic accounting research. Journal of Islamic Accounting and Business Research, 1(1), 5-9.

Hartono, A. 2016. Multi Paradigma Dalam Penelitian Akuntansi; Suatu Tinjauan Konsep. Ekuilibrium: Jurnal Ilmiah Bidang Ilmu Ekonomi, 7(1), 59-69.

Hasanah, N. 2009. Akuntansi Syariah Di Indonesia Prospek Dan Tantangannya Di Masa Depan. Al-Fikra, 8(1), 176-196.

Ikhsan, A., \& Suwarno, A. E. 2003. Membangun Standar Akuntansi Islam dari Perspektif Zakat. Jurnal Akuntansi dan Keuangan 2(2), 188-199.

Kamla, R., \& Alsoufi, R. 2015. Critical Muslim Intellectuals' discourse and the issue of 'Interest'(ribā): Implications for Islamic accounting and banking. Paper presented at the Accounting Forum.

Kamla, R., \& G. Rammal, H. 2013. Social reporting by Islamic banks: does social justice matter? Accounting, Auditing \& Accountability Journal, 26(6), 911-945.

Kartanegara, M. 2007. Mengislamkan Nalar: Sebuah Respon terhadap Modernitas: Erlangga.

Kuntowijoyo. 2008. Paradigma Islam: Interpretasi Untuk Aksi: PT Mizan Publika.

Ladewi, Y. 2014. The Role Of Islam Values (Ethics) In Accounting Practice And Impact Of Accounting Information Quality: A Library Study. International Journal of Economics, Commerce and Management, 2(12).

Lather, P. 1992. Critical frames in educational research: Feminist and post-structural perspectives. Theory into practice, 31(2), 87-99.

Lubis, D. S. 2015. Eksistensi Akuntansi Dalam Islam. Al-MASHARIF: Jurnal Ilmu Ekonomi dan Keislaman, 3(1), 72-85.

Maali, B., \& Napier, C. 2010. Accounting, religion and organisational culture: the creation of Jordan Islamic Bank. Journal of Islamic Accounting and Business Research, 1(2), 92-113.

Mulawarman, A. D. 2010. Integrasi Paradigma Akuntansi: Refleksi atas Pendekatan Sosiologi dalam Ilmu Akuntansi. Jurnal Akuntansi Multiparadigma, 1(1).

Napier, C. 2009. Defining Islamic accounting: current issues, past roots. Accounting History, 14(1-2), 121-144.

Niswatin. 2014. Iman Sebagai Konsep Dasar Penilaian Kinerja Bank Syariah: Studi Fenomenologi Islam. Dr Dissertation, Universitas Brawijaya, Malang.

Othman, R., \& Thani, A. M. 2010. Islamic social reporting of listed companies in Malaysia. The International Business \& Economics Research Journal, 9(4), 135.

Putralie, E. M., Syahputra, Y. A., \& Zul, M. 2011. Perlindungan Hukum Investor Di Pasar Modal. JURNAL MERCATORIA, 4(1), 26-36.

Saito, M., Hiramatsu, K., \& Mayangsari, S. 2012. Accounting Education for the Implementation of IFRS in Indonesia. International review of business(12), 121. 
Sarantakos, S. 2012. Social Research: Palgrave Macmillan.

Suprihatin, S., \& Tresnaningsih, E. 2013. Dampak konvergensi international financial reporting standards terhadap nilai relevan informasi akuntansi. Jurnal Akuntansi dan Keuangan Indonesia, 10(2), 171-183.

Terizaghi, T., \& Fitriasuri. 2014. Globalisasi Akuntansi: Implementasi Konvergensi IFRS Indonesia Dan Tantangannta Bagi UMKM. Sustainable Competitive Advantage (SCA), 4(1).

Tomkins, C., \& Karim, R. A. A. 1987. The Shari'ah and Its Implications for Islamic Financial Analysis: An Opportunity to Study Interactions Among Society, Organizations, and Accounting. American Journal of Islamic Social Sciences, 4(1), 101.

Triyuwono, I. 2011. "Sususaya" Melampaui Paradigma-Paradigma Metodologi Penelitian. Accounting Research Training Series 2 Jurusan Akuntansi Fakultas Ekonomi dan Bisnis - Universitas Brawijaya. Malang.

Triyuwono, I. 2015. So, What is Sharia Accounting? IMANENSI, 1(1), 42-50.

Triyuwono, I., Sukoharsono, E. G., \& Djamhuri, A. 2015. The Hegemony of International Interests on IFRS Adoption in Indonesia: An Accounting Ecology Perspective. Procedia-Social and Behavioral Sciences, 211, 104-110.

Utama, D. 2016. Upaya Perumusan Prinsip Counter Accounting Melalui Filosofi Punk Sebagai Counter Culture. Jurnal Akuntansi Multiparadigma, 6(3), 444-465.

Zarkasyi, H. F. 2013. Worldview Islam dan Kapitalisme Barat. TSAQAFAH, 9(1), 15 38. 